\title{
The Usability of E-learning Platforms in Higher Education: A Systematic Mapping Study
}

\author{
Khaled Abuhlfaia \\ Keele University \\ School of Computing and Mathematics \\ Staffordshire, UK, ST5 5BG \\ k.m.abuhlfaia@keele.ac.uk
}

\author{
Ed de Quincey \\ Keele University \\ School of Computing and Mathematics \\ Staffordshire, UK, ST5 5BG \\ e.de.quincey@keele.ac.uk
}

\begin{abstract}
The use of e-learning in higher education has increased significantly in recent years, which has led to several studies being conducted to investigate the usability of the platforms that support it. A variety of different usability evaluation methods and attributes have been used, and it has therefore become important to start reviewing this work in a systematic way to determine how the field has developed in the last 15 years. This paper describes a systematic mapping study that performed searches on five electronic libraries to identify usability issues and methods that have been used to evaluate e-learning platforms. Sixty-one papers were selected and analysed, with the majority of studies using a simple research design reliant on questionnaires. The usability attributes measured were mostly related to effectiveness, satisfaction, efficiency, and perceived ease of use. Furthermore, several research gaps have been identified and recommendations have been made for further work in the area of the usability of online learning.
\end{abstract}

\section{Usability, E-learning, Virtual Learning Environment, Higher Education, Systematic Mapping Study}

\section{INTRODUCTION}

Although the use of learning technology, commonly termed e-learning, has become the new norm in higher education, several studies have criticised the technologies developed to support it (Marković and Jovanović, 2012). The quality of learning received via technologies such as virtual learning environments (VLEs) often does not meet the expectations of students and teachers, with the usability of VLEs being one of the main factors affecting learning efficacy (Raspopovic et al., 2014) and one of the biggest factors faced by e-learning platform designers (Ardito et al., 2004). Usability plays an important role in the success of e-learning platforms, with end users spending a long time familiarising themselves with the platform's functionality, as it is not usable, instead of studying the content of the subject (Costabile et al., 2005). This means that the cost of poor usability is high, with learners left feeling frustrated (Plata and Alado, 2009), unsatisfied, and ineffective (Abedour and Smith, 2006).

Although in the last few decades several studies relating to the usability of e-learning platforms have been published, few reviews have evaluated and synthesised this information. This paper therefore describes a systematic mapping study (SMS) that has been undertaken following the methodology outlined by Kitchenham, Budgen and Brereton (2015). An SMS is a secondary study method used to identify and summarise the knowledge about a particular area contained in papers and articles; it also helps to categorise and evaluate information (Kitchenham and Charters, 2007; Kitchenham, Budgen and Brereton, 2015). The main aim of this mapping study is to identify the nature and extent of e-learning and usability research that has been conducted, focusing on areas such as the usability attributes measured, usability methods employed, and level of study of the participants.

Section 2 describes related platforms and reviews and section 3 outlines the methodology for the mapping study, including the search method and inclusion/exclusion criteria. Section 4 presents the results and sections 5 and 6 discuss the limitations and conclusions of this work.

\section{BACKGROUNDS AND RELATED WORK}

\subsection{E-learning Platforms}

The following section outlines some of the more common e-learning platforms (not including bespoke platforms made by universities to meet their particular needs (Jain, 2015)).

\subsubsection{Blackboard}

Matthew Pittinsky and Michael Chasen, introduced Blackboard in 1997. Blackboard is a Virtual Learning Environment (Logan and Neumann, 2010), where students are able to access course 
information (often in secured areas) and download and upload course materials and homework (Conrad, 2016). It can also be used to improve the efficiency of communication between learners and their institution. It supports a number of additional learning activities including conveying daily messages, tasks, course content, chat rooms, assignments, quizzes, exams, and grades (Eldridge, 2014).

\subsubsection{Modular Object-Oriented Dynamic Learning Environment (Moodle)}

The Moodle VLE platform is used widely all over the world by institutes, universities, companies and independent educators (Al-Ajlan and Zedan, 2008). It has been used by more than 94 million users in 233 countries (Moodle.org, 2018). Moodle was originally created by Martin Dougiamas in Australia in 1999, (Fuentes et al., 2012) and is an open source product (Kumar, Gankotiya and Dutta, 2011).

\subsubsection{Sakai}

Sakai is a platform developed by a group of academic institutions and commercial organizations, working together to develop a Collaborative Learning Environment (CLE) (Aggarwal et al., 2012). Sakai was released in 2005 and is currently on version 12.0, which was released in March 2018. Similar to Moodle, Sakai is an open source platform and has been used within e-learning by over 350 institutions and by 4 million learners around the world (Sakaiproject.org, 2018). However, to be able to modify the user-interface of Sakai you need to have relevant programming skills in this field (Chauhan et al., 2015).

\subsection{Previous Studies}

There have been two previous SMSs and several more general reviews in the area of the usability of e-learning platforms. However, the two previous studies have different aims to the study described in this paper, which are outlined in the following section.

\subsubsection{Nakamura, de Oliveira and Conte (2017)}

An SMS was performed by Nakamura, de Oliveira and Conte (2017) on the usability and user experience (UX) of learning management systems (LMS). This review aimed to analyse all studies that focused on LMS usability and UX evaluation techniques covering learning factors, type, availability performing method, restriction and origin, published between January 2004 and August 2016. The results of this SMS revealed that there is a need to study the lack of specific feedback given to address some of the issues and that more research is needed in the area of LMS.

The following are some of the main differences between our study and Nakamura et al.'s SMS.
Although the two studies have almost the same number of papers (62 and 61), due to a difference in the inclusion and exclusion criteria, we have included five papers that were excluded in their study and they included eight studies that we excluded. Nakamura et al.'s study included papers that are not related to higher education and included work related to mobile learning (which we have excluded). Moreover, our study has used Wiley Online Library and Google Scholar, whereas Nakamura et al. used only two databases, Scopus and Engineering Village (due to having limited access to various online libraries). Finally, we have covered a longer period, January 2002 to December 2016, as Nakamura et al. covered January 2004 to August 2016.

\subsubsection{Bernerus and Zhang (2010)}

A literature review (systematic review) based on the York methodology (Centre for Reviews and Dissemination, 2009) conducted by Bernerus and Zhang (2010) investigated usability evaluation methods (UEMs) for e-learning platforms, covering papers published between 2000 and 2010. They analysed relevant papers to determine how pedagogical aspects and criteria were treated when usability evaluations were performed. They then presented a summary of all the UEMs from their included studies and factors related to e-learning. However, some common evaluation methods were not found in the 27 papers they included, e.g. focus groups, interviews, and log file analysis. This study summarised four important pedagogical usability" factors: designing the content for learning, assessments, user's motivation to learn, and authoring supportive tools. Furthermore, they found that some studies were not fully aware of the importance of pedagogical aspects in usability (as opposed to general usability). However, their focus was limited to evaluation methods and limited by the lack of access to the full text of some articles. Moreover, the pedagogical usability factors summarised were based on their knowledge and what they had learnt from the case studies found. They admit that there may be other studies and usability factors that they have not considered (Bernerus and Zhang, 2010).

\subsubsection{Freire, Arezes and Campos (2012)}

Freire, Arezes and Campos (2012) presented a literature review about the relationship between ergonomics and usability in e-learning covering the last 30 years. There are no details regarding whether the research was conducted in a systematic or narrative way. The analysis of this review's results enabled the authors to identify three differences among the UEMs used dependent on whether the system's performance, the user's performance or the dialogue between users and systems was being evaluated. The majority of methods that were used to test 
e-learning's usability were the same as those used for general systems, i.e. not specialist methods. This study contained a variety of points of view, as it included researchers from different scientific areas, such as Ergonomics, Computer Science, and Education. The researchers' conclusion was that the most important point is knowing how to combine the most relevant methods for each type of evaluation and type of stakeholder.

\subsubsection{Plantak Vukovac, Kirinic and Klicek (2010)}

The aim of this review was to identify a set of criteria for choosing appropriate methods to test the usability of online learning platforms. In addition to analysing current UEMs for e-learning platforms, they compared UEMs for distance learning. The conclusion of this review was that factors relating to effectiveness, time, ease of application, cost and efficiency can affect the decision regarding which usability testing method to use on e-learning platforms (Ssemugabi and de Villers, 2007b). The authors also found that instructions for the methods are lacking and that more information would be needed if the methods were to be adopted by other researchers. However, this review covered a period up to 2010, whereas we have covered a period up to 2016 .

\subsubsection{Ssemugabi and de Villiers (2007b)}

The aim of this study was to compare the results of two evaluation methods on the Info3Net system: the UEMs and heuristic evaluation (HE). Ssemugabi and de Villiers (2007b) concluded that the results that were gathered using $\mathrm{HE}$ were similar to the result that was collected using a survey. However, more problems were identified by the four expert evaluators than the 61 students. Moreover, the HE conducted by the experts showed that it seemed to be an adequate and appropriate method to evaluate the e-learning systems.

\subsection{Conclusion}

Several reviews concerning the usability of elearning have been conducted. However, the mapping study described in this paper has a different focus and set of research questions as well as different inclusion and exclusion criteria and is based on a systematic, reproducible method.

\section{RESEARCH METHOD}

This SMS has been conducted in line with the guidelines provided by Kitchenham, Budgen and Brereton (2015), with the main stages shown in Figure 1. This section outlines the protocol of our SMS, including the research questions used to frame the study; the search strategy, e.g. which search strings, databases, and inclusion and exclusion criteria were used; and the rules for extracting data and classifying primary studies.

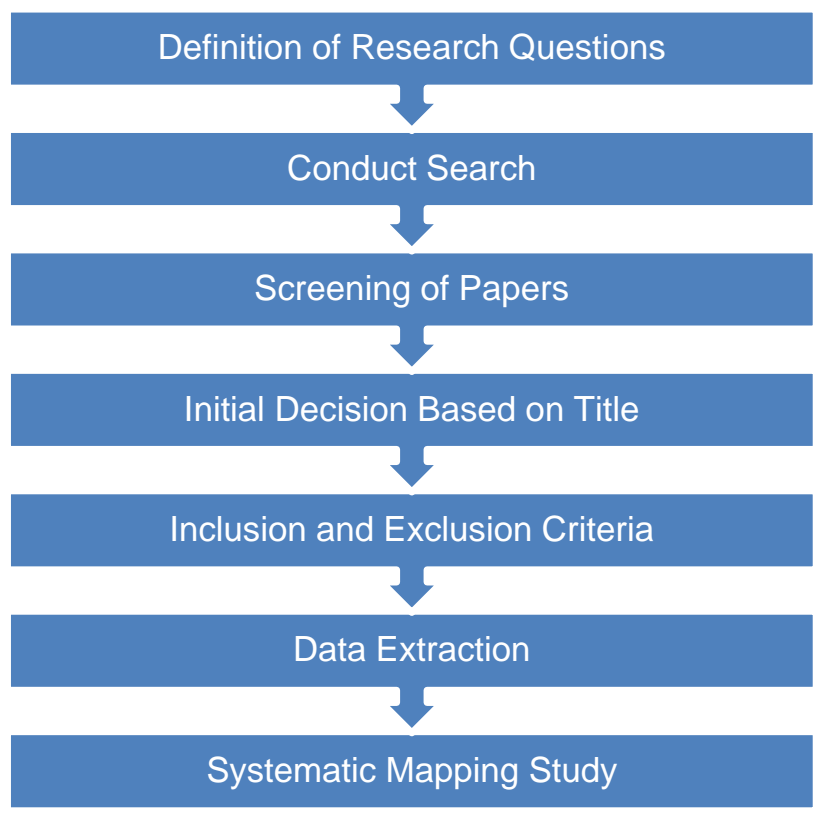

Figure 1: The Mapping Study Process

\subsection{Research Questions}

The following research questions were formulated to explore the areas of usability that contribute to the effectiveness and success of e-learning among students, staff and lecturers in universities:

RQ1. What are the main attributes that have been used to assess the usability of e-learning platforms?

RQ2. Which usability issues that have been identified in e-learning platforms?

RQ3. What methods/techniques are used to evaluate the usability of e-learning platforms?

RQ4. Which e-learning platform(s) has been evaluated?

RQ5. What was the level of study of the sample used in each paper?

RQ6. Which data analysis methods have been used?

RQ7. What data analysis tools have been used?

\subsection{Search strategy}

The search strategy aims to identify the most relevant literature related to the study area, focusing on research within articles, papers and journals Kitchenham and Charters (2007). The construction of the search strings followed the steps described by Brereton et al. (2007) and Kitchenham, Budgen and Brereton (2015).

1. Identify major terms and synonyms by terms that are used in the research questions. 
2. Identify different spellings and synonyms for major terms.

3. Use the Boolean operator "OR" to link alternative spellings and synonyms.

4. Use the Boolean operator "AND" to link major terms.

This resulted in the following keywords used in this search: ("Usability" OR "Usable" OR "ease of use" OR "user experience") AND ("E-learning" OR "Distance learning" OR "Distance education" OR "Elearning" OR "electronic learning").

The digital libraries used were the Institute of Electrical and Electronics Engineers (IEEE) Xplore Digital Library, Association for Computing Machinery (ACM) Digital Library, Google Scholar (search engine), Wiley Online Library, and ScienceDirect.

The search was limited to the period January 2002 to December 2016. The main reason for this was that e-learning platforms have been consistently updated and therefore versions before 2002 would not be representative of the current state of the art in the area. Moreover, the evolution of online technologies has had a significant effect on the delivery methods for e-learning courses, which again makes studies before 2002 less relevant.

To evaluate the validity of the search strings, ten key papers were identified from the relevant literature. An initial pilot search was then undertaken using the proposed search strings to test whether these key papers would be returned in the results. The search strings were then adjusted dependent on the results and each database's particular search criteria.

\subsection{Search process}

The full search strings were then inputted into each of the chosen digital libraries. All papers were downloaded based on their titles at this stage. The details of all the returned papers were then imported into the Mendeley software, helping the researcher to remove all instances of duplicate papers from different digital libraries. Next, the inclusion and exclusion criteria outlined in the following section were applied. This is where the papers were successively screened based on their relevance for the current review.

\subsection{Inclusion and exclusion criteria}

The first author carried out an initial selection process by applying the criteria to the title of all downloaded papers. If it was not clear whether the paper complied with an inclusion or exclusion criteria, it was included for further screening, which involved reading the abstract for each study and if needed, the introduction and conclusions. In some cases, it was necessary to read the full text to decide whether the paper was to be included in this study. The full details are in Tables 1 and 2 .

Table 1: Inclusion Criteria

\begin{tabular}{|l|l|}
\hline No & \multicolumn{1}{c|}{ Inclusion } \\
\hline 1 & $\begin{array}{l}\text { Papers published between January 2002 and } \\
\text { December 2016. }\end{array}$ \\
\hline 2 & Written in the English language. \\
\hline 3 & $\begin{array}{l}\text { Peer-reviewed literature (conference proceedings } \\
\text { and journal articles). }\end{array}$ \\
\hline 4 & $\begin{array}{l}\text { Paper which includes a description of evaluation } \\
\text { about the usability of e-learning and has a clear } \\
\text { method. }\end{array}$ \\
\hline 5 & $\begin{array}{l}\text { Combine users if the platforms were in Higher } \\
\text { Education. }\end{array}$ \\
\hline 6 & $\begin{array}{l}\text { Papers presenting usability attributes other } \\
\text { usability problems. }\end{array}$ \\
\hline
\end{tabular}

Table 2: Exclusion Criteria

\begin{tabular}{|l|l|}
\hline No & \multicolumn{1}{|c|}{ Exclusion } \\
\hline 1 & $\begin{array}{l}\text { Duplicate papers from the same study in different } \\
\text { databases. }\end{array}$ \\
\hline 2 & Publications not written in English. \\
\hline 3 & Publications not directly related to our topic. \\
\hline 4 & Where the data analysis process is not presented. \\
\hline 5 & Publications related to the evaluation of materials. \\
\hline 6 & Non-reviewed literature. \\
\hline 7 & $\begin{array}{l}\text { Study sample, which concerned about disabled } \\
\text { users. }\end{array}$ \\
\hline
\end{tabular}

\subsection{Data extraction strategy}

This section outlines the collection of data from each of the included papers. A spreadsheet was created to store the extracted information from each of the included studies with each row representing one article, enabling further comparison and analysis. Meta-data was collected from each paper, such as the title of the paper, the authors, publication year, place of publication, and abstract (see Table 3). To achieve the objectives of this SMS, more specific data, for instance, the usability attributes considered (based on those specified by Nielsen [1993] and the International Standards Organization (ISO) [1998]), the method used, and the sample size, was needed to answer the research questions. The full details are in Table 3 below.

Table 3: Data Extraction

\begin{tabular}{|l|l|l|}
\hline Code & \multicolumn{1}{|c|}{ Field /Data } & \multicolumn{1}{|c|}{$\begin{array}{c}\text { Related } \\
\text { Research } \\
\text { Question }\end{array}$} \\
\hline D1 & Paper ID & Documentation \\
\hline D2 & Title of publication & Documentation \\
\hline D3 & $\begin{array}{l}\text { Abstract and bibliography } \\
\text { reference }\end{array}$ & Documentation \\
\hline D4 & Author Name(s) & Documentation \\
\hline D5 & $\begin{array}{l}\text { Academic departments } \\
\text { authors are affiliated with. }\end{array}$ & Documentation \\
\hline
\end{tabular}




\begin{tabular}{|l|l|l|}
\hline$D 6$ & Publication source & Documentation \\
\hline$D 7$ & Year of publication & Documentation \\
\hline$D 8$ & Type of publication & Documentation \\
\hline$D 9$ & E-learning platforms tested & $R Q 4$ \\
\hline$D 10$ & Aims and objectives & Documentation \\
\hline$D 11$ & $\begin{array}{l}\text { Research question(s) and/or } \\
\text { hypothesis stated }\end{array}$ & Documentation \\
\hline$D 12$ & $\begin{array}{l}\text { Usability attributes used for } \\
\text { assessment }\end{array}$ & $R Q 1$ \\
\hline$D 13$ & $\begin{array}{l}\text { Name of the evaluation } \\
\text { methods used. }\end{array}$ & $R Q 3$ \\
\hline$D 14$ & Number of participants & Documentation \\
\hline$D 15$ & Participants in the study & Documentation \\
\hline$D 16$ & Level of Education & $R Q 5$ \\
\hline$D 17$ & Tasks participants given & Documentation \\
\hline$D 18$ & $\begin{array}{l}\text { Usability problems found } \\
\text { Data analysis tools used }\end{array}$ & $R Q 2$ \\
\hline$D 19$ & Data analysis methods used & $R Q 7$ \\
\hline$D 20$ & $\begin{array}{l}\text { Conclusion and } \\
\text { recommendations }\end{array}$ & Documentation \\
\hline$D 21$ & \\
\hline
\end{tabular}

\subsubsection{Validation}

To validate the inclusion and exclusion process, the two authors cross-checked 22 articles and agreed that all of them met the exclusion criteria.

To validate the data extraction process, the protocol was piloted with the two authors and an expert in SMS authors, who compared data extraction results across ten papers until a suitable level of agreement was met.

The first author of this paper then extracted the data for the 61 publications included in the study. To be fully satisfied that the information gathered was accurate, all included papers were read in full at this stage.

\section{RESULTS AND ANALYSIS}

A total of 7,767 hits resulted from searches using the specified search strings on Google Scholar and the chosen databases, ACM Digital Library, Wiley Online Library, IEEE Xplore, and ScienceDirect. The methodology described in section 3 was then followed with 199 papers downloaded from Google Scholar and the chosen libraries based on the titles of the publications found.

A secondary selection was then made based on reading the abstracts, introductions and conclusions and applying the inclusion and exclusion criteria. This resulted in 53 failing to meet the inclusion criteria and 146 remaining papers that needed to be read in full (and the inclusion and exclusion criteria applied). Following this process, a total of 61 articles were included in the study (32 conferences papers and 29 journal articles, see Figure 2). The following table shows the number of papers found and included from each of the chosen libraries. The majority of the papers were downloaded from Google Scholar and only three papers were from Wiley Online Library. Figure 2 shows the distribution of papers over years and the place of publication.

Table 4: The numbers of searches found from the chosen libraries between 2002 and 2016

\begin{tabular}{|c|c|c|c|c|}
\hline 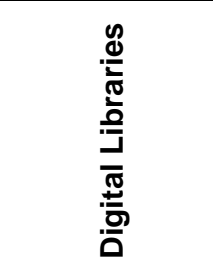 & 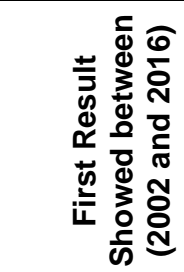 &  & 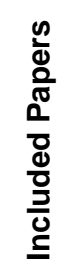 & 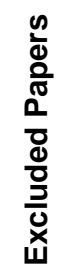 \\
\hline Google & 193 & 128 & 31 & 97 \\
\hline ScienceDirect & 256 & 16 & 11 & 5 \\
\hline IEEE & 2,932 & 32 & 10 & 22 \\
\hline$A C M$ & 3,861 & 12 & 6 & 6 \\
\hline Wiley & 525 & 11 & 3 & 8 \\
\hline Total numbers & 7,767 & 199 & 61 & 138 \\
\hline
\end{tabular}

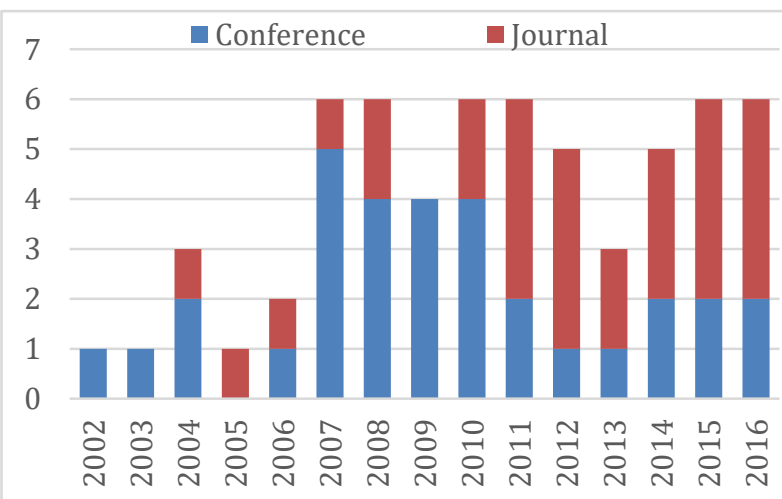

Figure 2: The distribution of papers over years

The following section reviews the primary results of the mapping study as well as the potential limitations. It provides the answer for each research question.

Results for RQ1 "What are the main attributes that have been used to assess the usability of $e$ learning platforms?". Table 5 illustrates the main usability attributes that have been explored by the primary studies. Effectiveness was the main attribute that has been investigated with 23 studies, followed by satisfaction (19), then efficiency (17). However, there was less focus on learnability and memorability, with 14 and 8 papers respectively. Perceived ease of use was explored in 14 studies and perceived usefulness in 11 papers. However, 12 papers did not specify which usability problems they studied.

We found that there are more papers focusing on effectiveness and satisfaction when evaluating elearning systems. However, only a few papers considered error and memorability, highlighting the potential need for more work in this area. 
Table 5: The usability attributes used for assessment

\begin{tabular}{|c|c|c|}
\hline $\begin{array}{c}\text { Usability } \\
\text { attributes } \\
\text { used for } \\
\text { assessment }\end{array}$ & Paper's Reference No. & $\begin{array}{l}\text { No. of } \\
\text { Papers }\end{array}$ \\
\hline Effectiveness & $\begin{array}{l}P 1, P 3, P 6, P 8, P 11, P 24, \\
P 26, P 28, P 33, P 37, P 41, \\
P 42, P 44, P 45, P 48, P 50, \\
P 52, P 54, P 55, P 58, P 59, \\
P 60, P 61 .\end{array}$ & 23 \\
\hline Satisfaction & $\begin{array}{l}P 3, P 7, P 11, P 15, P 18, P 21, \\
P 23, P 26, P 27, P 31, P 39, \\
P 41, P 42, P 45, P 52, P 54, \\
P 57, P 58, P 59 .\end{array}$ & 19 \\
\hline Efficiency & $\begin{array}{l}P 6, P 7, P 9, P 13, P 18, P 26, \\
P 32, P 42, P 44, P 45, P 51, \\
P 52, P 55, P 56, P 58, P 59, \\
P 60 .\end{array}$ & 17 \\
\hline $\begin{array}{l}\text { Perceived } \\
\text { ease of use }\end{array}$ & $\begin{array}{l}P 3, P 10, P 15, P 17, P 21, P 25, \\
P 27, P 30, P 31, P 34, P 36, \\
P 43, P 47, P 54,\end{array}$ & 14 \\
\hline Learnability & $\begin{array}{l}P 1, P 7, P 8, P 9, P 13, P 16, \\
P 20, P 22, P 32, P 37, P 39, \\
P 56, P 61 .\end{array}$ & 13 \\
\hline $\begin{array}{l}\text { Not specific } \\
\text { just usability } \\
\text { issues }\end{array}$ & $\begin{array}{l}P 5, P 12, P 14, P 20, P 24, P 29, \\
P 31, P 35, P 38, P 40, P 46, \\
P 48 .\end{array}$ & 12 \\
\hline $\begin{array}{l}\text { Perceived } \\
\text { usefulness }\end{array}$ & $\begin{array}{l}P 3, P 15, P 17, P 19, P 21, P 25, \\
P 27, P 34, P 43, P 47, P 54 .\end{array}$ & 11 \\
\hline Memorability & $\begin{array}{l}\text { P3, P4, P7, P32, P39, P41, } \\
\text { P54, P61. }\end{array}$ & 8 \\
\hline Error & $P 39$. & 1 \\
\hline
\end{tabular}

Results for RQ2. "Which usability issues that have been identified in e-learning platforms?". Although Nielsen and the ISO identified six main usability attributes (used in RQ1), there are other, more specific usability problems that affect the UX on elearning platforms, which are also useful to classify. Table 6 shows a number of common usability problems that have been identified. Information quality was the most common problem found with eight studies, followed by attitude to use the system (7) and navigation (6). Helpfulness was found in four studies. However, 22 of the 61 papers did not specify which usability problems they encountered.

Table 6: The Usability issues that have been identified in e-learning platforms

\begin{tabular}{|l|l|l|}
\hline $\begin{array}{l}\text { Particular } \\
\text { usability } \\
\text { problems }\end{array}$ & \multicolumn{1}{|c|}{ Paper's Reference No. } & $\begin{array}{l}\text { No. of } \\
\text { Papers }\end{array}$ \\
\hline $\begin{array}{l}\text { Not } \\
\text { specified } \\
\text { (general } \\
\text { usability } \\
\text { issues)" }\end{array}$ & $\begin{array}{l}\text { P2, P4, P5, P6, P8, P14, P17, } \\
\text { P34, P21, P24, P26, P28, P32, } \\
\text { P51, P52, P59. }\end{array}$ & 22 \\
\hline $\begin{array}{l}\text { Information } \\
\text { quality }\end{array}$ & $\begin{array}{l}\text { P19, P10, P27, P29, P31, P36, } \\
\text { P47, P57. }\end{array}$ & 8 \\
\hline Attitude & $\begin{array}{l}P 3, P 15, P 20, P 33, P 37, P 42, \\
P 54 .\end{array}$ & 7 \\
\hline Navigation & $P 1, P 10, P 16, P 25, P 49$, P54. & 6 \\
\hline
\end{tabular}

\begin{tabular}{|l|l|l|}
\hline Helpfulness & $P 7, P 9, P 13, P 56$. & 4 \\
\hline Control & $9,13,56$. & 3 \\
\hline Flexibility & $P 37, P 61$. & 2 \\
\hline Reliability & $P 37, P 61$. & 2 \\
\hline $\begin{array}{l}\text { User } \\
\text { interface }\end{array}$ & $P 10$. & 1 \\
\hline Colour & $P 29$. & 1 \\
\hline
\end{tabular}

Results for RQ3 "What are the methods/techniques used to evaluate the usability of e-learning platforms?". Table 7 below shows the usability evaluation/testing methods that were used in the included papers. A questionnaire was the main method used in 50 studies, followed by interviews (12) and observation (9). Focus groups were used in five studies and think aloud in six studies. HE was used in three papers and eye tracking in two.

Although a questionnaire was the main overall method used, 16 studies combined two methods or more, e.g. interview and observation. Specific types of questionnaire included the System Usability Scale (SUS), the Software Usability Measurement Inventory (SUMI), and the web-based learning and usability questionnaire (WLUQ). However, a number of studies did not give details about the type of questionnaire or questions they used, something that would be useful for future studies.

Table 7: The name of evaluation methods used

\begin{tabular}{|c|c|c|}
\hline Methods used & Paper's Reference No. & $\begin{array}{l}\text { No. of } \\
\text { Papers }\end{array}$ \\
\hline Questionnaire & $\begin{array}{l}P 2, P 3, P 4 P 5, P 7, P 8, P 9, \\
P 11, P 12, P 13, P 15, P 16, \\
P 17, P 18, P 19, P 20, P 21, \\
P 22, P 23, P 24, P 25, P 26, \\
P 27, P 28, P 29, P 30, P 31, \\
P 33, P 34, P 35, P 36, P 37, \\
P 38, P 39, P 40, P 41 P 43, \\
P 44, P 45, P 46, P 47, P 48, \\
P 50, P 53, P 54 P 56, P 57, \\
P 58, P 60, P 61 .\end{array}$ & 50 \\
\hline Interviewing & $\begin{array}{l}P 1, P 6, P 10, P 16, P 22, \\
P 32, P 34, P 43, P 46, P 50, \\
P 55, P 60 .\end{array}$ & 12 \\
\hline Observation & $\begin{array}{l}P 1, P 9, P 14, P 32, P 38, \\
P 39, P 43, P 46, P 55 .\end{array}$ & 9 \\
\hline Thinking Aloud & $\begin{array}{l}\text { P6, P16, P32, P42, P43, } \\
\text { P55. }\end{array}$ & 6 \\
\hline $\begin{array}{l}\text { Focus Group } \\
\text { interview }\end{array}$ & P2, P31, P50, P51, P59. & 5 \\
\hline $\begin{array}{l}\text { Heuristic } \\
\text { Evaluation }\end{array}$ & P2, P49, P53. & 3 \\
\hline Eye Tracking & $P 1, P 46$. & 2 \\
\hline $\begin{array}{l}\text { Empirical } \\
\text { analysis. }\end{array}$ & P11. & 1 \\
\hline $\begin{array}{l}\text { Audio } \\
\text { Recording }\end{array}$ & P43. & 1 \\
\hline $\begin{array}{l}\text { Group Task } \\
\text { Analysis }\end{array}$ & P52. & 1 \\
\hline $\begin{array}{l}\text { Mental rotations } \\
\text { test }(M R T)\end{array}$ & P38. & 1 \\
\hline $\begin{array}{l}\text { Screen } \\
\text { Recording }\end{array}$ & P46. & 1 \\
\hline
\end{tabular}


The table below shows a breakdown of the types of questionnaire that were used. SUS was used in seven studies, SUMI was used in four studies, and each of the other questionnaires was used in one study.

Table 8: The types of questionnaire used

\begin{tabular}{|l|l|l|}
\hline \multicolumn{1}{|c|}{$\begin{array}{c}\text { Usability testing } \\
\text { methods used }\end{array}$} & \multicolumn{1}{|c|}{$\begin{array}{c}\text { Paper's } \\
\text { Reference No. }\end{array}$} & $\begin{array}{c}\text { No. of } \\
\text { Papers }\end{array}$ \\
\hline SUS & $\begin{array}{l}\text { P3, P12, P23, } \\
\text { P26, P41, P45, } \\
\text { P48, }\end{array}$ & 7 \\
\hline SUMI & $\begin{array}{l}\text { P8, P9, P13, } \\
\text { P56. }\end{array}$ & 4 \\
\hline $\begin{array}{l}\text { Questionnaire for User } \\
\text { Interaction Satisfaction } \\
\text { short form }\end{array}$ & $p 46$ & 1 \\
\hline $\begin{array}{l}\text { Bill Gillham } \\
\text { Questionnaire }\end{array}$ & $p 2$ & 1 \\
\hline WLUQ & $P 19$ & 1 \\
\hline $\begin{array}{l}\text { Computer System } \\
\text { Usability Questionnaire }\end{array}$ & $p 47$ & 1 \\
\hline UEQ & $P 60$ & 1 \\
\hline
\end{tabular}

Results for RQ4 "Which e-learning platform(s) has been evaluated?". Table 9 shows that bespoke elearning systems were evaluated in 20 papers and that the term LMS was used to describe platforms in 13 studies. Moodle was used in 12 studies; however, it is worth noting that some studies used both LMS and Moodle (studies 21, 50 and 51). The generic terms VLEs (7), web-based platforms and course management system (CMS) were used in three studies. However, 17 studies did not mention which platform they tested.

Table 9: The e-learning platforms tested

\begin{tabular}{|l|l|l|}
\hline $\begin{array}{c}\text { Platforms } \\
\text { tested }\end{array}$ & \multicolumn{1}{|c|}{ Paper's Reference No. } & $\begin{array}{c}\text { No. of } \\
\text { Papers }\end{array}$ \\
\hline $\begin{array}{l}\text { E-learning } \\
\text { system }\end{array}$ & $\begin{array}{l}\text { P1, P2, P9, P10, P12, P20, } \\
\text { P21, P28, P30, P31, P32, P37, } \\
\text { P38, P47, P48, P49, P50, P52, } \\
\text { P56, P61. }\end{array}$ & 20 \\
\hline $\begin{array}{l}\text { Not } \\
\text { specified }\end{array}$ & $\begin{array}{l}P 6, P 8, P 16, P 25, P 28, P 30, \\
P 33, P 34, P 39, P 40, P 41, P 42, \\
P 46, P 51, P 55, P 57, P 59 .\end{array}$ & 17 \\
\hline LMS & $\begin{array}{l}P 5, P 11, P 14, P 18, P 22, P 24, \\
P 29, P 35, P 36, P 43, P 53, P 54,\end{array}$ & 13 \\
& $P 60$. & \\
\hline Moodle & $\begin{array}{l}P 4, P 5, P 7, P 13, P 22, P 23, \\
P 26, P 36, P 43, P 54, P 58, P 60 .\end{array}$ & 12 \\
\hline VLE & $\begin{array}{l}P 3, P 4, P 5, P 27, P 44, P 45, \\
P 58 .\end{array}$ & 7 \\
\hline CMS & $P 13, P 19, P 50$. & 3 \\
\hline Web-based & $P 7, P 18, P 24$. & 3 \\
\hline Webinar & $P 17$. & 1 \\
\hline
\end{tabular}

Results for RQ5 "What was the level of study of the sample used in each paper?". The table below classifies the participants in the study based on their level of study. The users in 27 papers were undergraduate students, followed by master's students with 14, PhD students with six, expert users with three, and administrators with two.

Many studies emphasise that the participants' level of education may affect the usability of the elearning platforms, so it is concerning that 23 papers did not mention the level of study of respondents. Overall, undergraduate students were the main users to test the systems, with very few studies targeting expert users and administrative staff.

Table 10: The level of education of users

\begin{tabular}{|c|c|c|}
\hline $\begin{array}{c}\text { Users level of } \\
\text { study }\end{array}$ & Paper's Reference No. & $\begin{array}{l}\text { No. of } \\
\text { Papers }\end{array}$ \\
\hline Undergraduate & $\begin{array}{l}P 1, P 2, P 3, P 4, P 9, P 10, \\
P 12, P 13, P 20, P 22, P 23, \\
P 24, P 31, P 34, P 35, P 36, \\
P 37, P 38, P 39, P 42, P 43, \\
P 44, P 48, P 51, P 54, P 56, \\
P 61 .\end{array}$ & 27 \\
\hline Not specified & $\begin{array}{l}P 7, P 8, P 11, P 14, P 15, P 16, \\
P 17, P 18, P 19, P 25, P 28, \\
P 29, P 30, P 32, P 33, P 40, \\
P 43, P 46, P 50, P 53, P 58, \\
P 59, P 60,\end{array}$ & 23 \\
\hline $\begin{array}{l}\text { Postgraduate } \\
\text { Taught }\end{array}$ & $\begin{array}{l}P 2, P 5, P 6, P 21, P 22, P 23, \\
P 27, P 39, P 41, P 45, P 47, \\
P 52, P 55, P 57 .\end{array}$ & 14 \\
\hline Lecture & $\begin{array}{l}P 2, P 22, P 26, P 28, P 34, \\
P 43, P 51 .\end{array}$ & 7 \\
\hline Ph.D. & $\begin{array}{l}\text { P2, P22, P23, P39, P41, } \\
\text { P49. }\end{array}$ & 6 \\
\hline Expert users & $P 2, P 23, P 43$. & 3 \\
\hline Administrations & P43, P51. & 2 \\
\hline
\end{tabular}

Results for RQ6 "Which data analysis methods have been used?". The table below shows software that has been used to analyse the results from the usability evaluations/tests, such as SPSS (9), LISREL (2), and two other tools, Tobii Studio and QSR Nvivo, each of which was used in one study. However, the majority of papers did not indicate which software they used to analyse their data.

Table 11: The data analysis methods used

\begin{tabular}{|l|l|l|}
\hline $\begin{array}{c}\text { Data analysis } \\
\text { tools used }\end{array}$ & Paper's Reference No & $\begin{array}{c}\text { No. of } \\
\text { Papers }\end{array}$ \\
\hline SPSS & $\begin{array}{l}\text { P14, P20, P21, P23, } \\
\text { P28, P31, P34, P44, } \\
P 46 .\end{array}$ & 9 \\
\hline $\begin{array}{l}\text { Tested using } \\
\text { LISREL 8.50. }\end{array}$ & $P 15, P 57$. & 2 \\
\hline $\begin{array}{l}\text { Tobbi T60 named } \\
\text { Tobii Studio. }\end{array}$ & $P 1$. & 1 \\
\hline $\begin{array}{l}\text { QSR Nvivo } \\
\text { software }\end{array}$ & $P 46$. & 1 \\
\hline
\end{tabular}

Results for RQ7 "What data analysis tools have been used?". Table 12 shows the data analysis methods used. Of the 61 studies, 39 used descriptive analysis, followed by Cronbach's alpha coefficient with 16, and ANOVA test with eight. 
Moreover, Structural Equation Modeling (SEM) and Partial least square (PLS) tests were each used in three studies, a Chi-square statistical test and squared multiple correlation (SMC) were used in two studies, and finally, five studies used other tests. However, 14 studies did not provide information about the data analysis methods used.

Table 12: The data analysis tools used

\begin{tabular}{|c|c|c|}
\hline $\begin{array}{l}\text { Data analysis } \\
\text { methods used }\end{array}$ & Paper's Reference No. & $\begin{array}{r}\text { No. of } \\
\text { Papers }\end{array}$ \\
\hline $\begin{array}{l}\text { Descriptive } \\
\text { analyses }\end{array}$ & $\begin{array}{l}P 1, P 3, P 4, P 7, P 10, P 11, \\
P 13, P 14, P 17, P 18, P 19, \\
P 20, P 21, P 22, P 23, P 25, \\
P 27, P 28, P 29, P 31, P 34, \\
P 35, P 36, P 37, P 39, P 40, \\
P 41, P 42, P 43, P 44, P 45, \\
P 47, P 48, P 54, P 56, P 57, \\
P 58, P 60, P 61 .\end{array}$ & 39 \\
\hline $\begin{array}{l}\text { Cronbach-Alpha } \\
\text { coefficient }\end{array}$ & $\begin{array}{l}P 8, P 11, P 15, P 21, P 23, \\
P 26, P 30, P 33, P 34, P 35, \\
P 36, P 39, P 40, P 57, P 60, \\
P 61 .\end{array}$ & 16 \\
\hline Not specified & $\begin{array}{l}P 5, P 6, P 12, P 16, P 24, \\
P 32, P 46, P 49, P 50, P 51, \\
P 52, P 53, P 55, P 59 .\end{array}$ & 14 \\
\hline ANOVA & $\begin{array}{l}\text { P9, P18, P19, P26, P35, } \\
\text { P38, P44, P45. }\end{array}$ & 8 \\
\hline $\begin{array}{l}\text { Average } \\
\text { Variance } \\
\text { Extracted }\end{array}$ & P21, P27, P47, P54, P57. & 5 \\
\hline$P L S$ & $P 4, P 21, P 47, P 54$. & 4 \\
\hline SEM & $P 4, P 15, P 27$. & 3 \\
\hline $\begin{array}{l}\text { Chi-square } \\
\text { statistical test }\end{array}$ & $P 15, P 41$. & 2 \\
\hline$S M C$ & $P 27, P 58$. & 2 \\
\hline
\end{tabular}

Interestingly, there were no papers that used any form of automated usability testing, which can often be applied in the early stages of usability testing.

\section{LIMITATIONS}

The limitations of this study relate to misclassification, publication bias, selection bias, and inexactness in data extraction. SMSs suffer from the common issue of publication bias, i.e. negative results may not be published or cited, and positive results may be published faster than negative results (Kitchenham, Budgen and Brereton, 2015).

Selection bias refers to the misrepresentation of statistical analysis due to criteria that have been used in the selection of published papers (Fernandez et al., 2011). To try to mitigate this threat, detailed inclusion/exclusion criteria were determined and validated by the authors. A related issue is that during data extraction, it is possible that information is overlooked or misclassified by reviewers. To mitigate this threat, the extraction and classification of the studies were conducted by the first author, with cross-checking by the two authors and an expert in SMS on ten papers until the protocol and extraction process was agreed upon and standardised.

\section{CONCLUSIONS AND FUTURE WORK}

This SMS aimed to answer seven research questions concerning the usability of e-learning in higher education. We have presented the current state of the art according to 61 papers containing primary studies. Although there are two similar previous SMSs in this area, they each have a different focus and research questions.

The findings of this study suggest that adding other usability factors, such as navigation and attitude, to the standard usability attributes and using a combination of evaluation methods, such as focus groups and questionnaires, would be useful. There seems to be reliance on questionnaires, which miss tacit and semi-tacit knowledge but need to link to the literature in this area (Rugg and Petre, 2007). Moreover, some studies did not provide certain vital information, for example, the platform they tested, the participants' background, and the tools they used to analyse their data.

This mapping study gives a clear idea of the usability of e-learning to guide future researchers in this area. We observed that a few studies used the methods focus group, heuristic evaluation, and eye tracking, as well as some usability factors, for instance perceived usefulness, memorability, and error. In the previous paper by Harrati et al. (2016), they expressed the opinion that it is possible to investigate the usability factors of memorability and learnability, and their relationship with ease-of-use over time by analysing the participant's usage logs. Our mapping study has demonstrated that such an approach has not been used to date in primary studies.

We hope that our findings will identify several research gaps for future research, such as which of the most appropriate usability techniques can be applied to evaluate e-learning platforms.

\section{ACKNOWLEDGMENTS}

We would like to acknowledge Azzaytuna University and the Libyan Ministry of Higher Education and Scientific Research for the PhD scholarship provided for Khaled Abuhlfaia. We would also like thank our colleague Professor Pearl Brereton for her useful comments and suggestions. 


\section{REFERENCES}

Aberdour, M., \& Smith, R. (2006). Usability in elearning. Online: http://www.epic.co.uk/content/resources/white_p apers/pdf_versions/Development/Epic_White_P aper_Us ability.pdf (accessed 19.09.08)

Adeoye, B., \& Wentling, R. M. (2007). The relationship between national culture and the usability of an e-learning system. International Journal on ELearning, 6(1), 119-146. (Ref P39)

Aggarwal, A., Adlakha, V., \& Ross, T. (2012). A Hybrid approach for selecting a course management system: A case study. Journal of Information Technology Education: Innovations in Practice, 11, 283-300.

Al-Ajlan, A., \& Zedan, H. (2008). Why moodle. In Future Trends of Distributed Computing Systems, 2008. FTDCS'08. 12th IEEE International Workshop on (pp. 58-64). IEEE.

Alseid, M., \& Rigas, D. (2010). Three different modes of avatars as virtual lecturers in elearning interfaces: a comparative usability study. The Open Virtual Reality Journal, Bentham Open, ISSN: 1875-323X 2(1), 8-17. (Ref P45)

Alseid, M., \& Rigas, D. (2011). The role of earcons and auditory icons in the usability of avatarbased e-learning interfaces. In Developments in E-systems Engineering (DeSE), 2011 (pp. 276281). IEEE. (Ref P41)

Alseid, M., Azzeh, M., \& El Sheikh, Y. (2014). A Comparative Usability Study on the Use of Auditory Icons to Support Virtual Lecturers in ELearning Interfaces. Journal of Advanced Computer Science \& Applications, 5(4). (Ref P3)

Alshammari, M., Anane, R., \& Hendley, R. J. (2015). Design and usability evaluation of adaptive e-learning systems based on learner knowledge and learning style. In HumanComputer Interaction (pp. 584-591). Springer, Cham. (Ref P12)

Alshammari, M., Anane, R., \& Hendley, R. J. (2016, May). Usability and effectiveness evaluation of adaptivity in e-learning systems. In Proceedings of the $2016 \mathrm{CHI}$ Conference Extended Abstracts on Human Factors in Computing Systems (pp. 2984-2991). ACM. (Ref P48)

Ardito, C., Costabile, M. F., De Marsico, M., Lanzilotti, R., Levialdi, S., Roselli, T., \& Rossano, V. (2006). An approach to usability evaluation of e-learning applications. Universal access in the information society, 4(3), 270-283. (Ref P6)

Ardito, C., De Marsico, M., Lanzilotti, R., Levialdi, S., Roselli, T., Rossano, V., \& Tersigni, M. (2004, May). Usability of e-learning tools.
In Proceedings of the working conference on Advanced visual interfaces (pp. 80-84). ACM. (Ref 55)

Asarbakhsh, M. \& Sandars, J. (2013). E- learning: the essential usability perspective. The clinical teacher. 10 (1): 47-50. (Ref P16)

Bernerus, A., \& Zhang, J. (2010). A Peek at the Position of Pedagogical Aspects in Usability Evaluation of E-learning System-A Literature Review of Usability Evaluation of E-learning System conducted since 2000 (Bachelor's thesis).

Berns, T. (2004). Usability and user-centred design, a necessity for efficient e-learning. International Journal of The Computer, the Internet and Management. 12 (2): 20-25. (Ref P51)

Blake, C. T., \& Rapanotti, L. (2004). Usability evaluation of distributed groupware in distance learning. In Information Technology Based Higher Education and Training, 2004. ITHET 2004. Proceedings of the Flfth International Conference on (pp. 500-504). IEEE. (Ref P52)

Brereton, P., Kitchenham, B.A., Budgen, D., Turner, M. \& Khalil, M. (2007). Lessons from applying the systematic literature review process within the software engineering domain. Journal of Systems and Software. 80 (4): 571-583.

Bubaš, G., Orehovački, T., Balaban, I., \& Ćorić, A. (2010). Evaluation of Web 2.0 tools in the elearning context: Case studies related to pedagogy and usability. In University Information Systems-Selected Problems. Difin SA. (Ref P25)

Celik, S. (2012). Development of usability criteria for e-learning content development software. Turkish Online Journal of Distance Education. 13 (2), 336-345. (Ref P14)

Chauhan, J., Batbayar, K., Sharma, R., Sharma, D., Popli, D., Kumar, N., \& Goel, A. (2015). Towards Adapting Sakai for e-Learning Provider. In CSEDU (1) (pp. 306-314).

Chiu, C. M., Hsu, M. H., Sun, S. Y., Lin, T. C., \& Sun, P. C. (2005). Usability, quality, value and elearning continuance decisions. Computers \& education, 45(4), 399-416. (Ref P57)

Chuah, Y. F., Fong, L. F., \& Zaki, Z. M. (2016). Learners' Evaluat ion of the Usability and Design Features of Chinese as a Foreign Language ELearning Websites. International Journal of Learning and Teaching, 2(1), 91-98. (Ref P31)

Conrad, K. A. (2016). Developing and Implementing a LGBT Family Studies Course: A Pre-Post Evaluation.

Costabile, M. F., De Marsico, M., Lanzilotti, R., Plantamura, V. L., \& Roselli, T. (2005). On the 
usability evaluation of e-learning applications. In System Sciences, 2005. HICSS'05. Proceedings of the 38th Annual Hawaii International Conference on (pp. 6b-6b). IEEE.

Costagliola, G., De Lucia, A., Ferrucci, F., Gravino, C., \& Scanniello, G. (2008). Assessing the usability of a visual tool for the definition of $e$ learning processes. Journal of Visual Languages \& Computing, 19(6), 721-737. (Ref P11)

Deraniyagala, R., Amdur, R.J., Boyer, A.L. \& Kaylor, S. (2015). Usability study of the EduMod eLearning Program for contouring nodal stations of the head and neck. Practical radiation oncology. 5 (3): 169-175. (Ref P56)

Doubleday, E. G., O'Loughlin, V. D., \& Doubleday, A. F. (2011). The virtual anatomy laboratory: Usability testing to improve an online learning resource for anatomy education. Anatomical sciences education, 4(6), 318-326. (Ref P44)

Eldridge, B. A. (2014). Exploring faculty adoption and utilization of Blackboard at a community college in the Kentucky Community and Technical College System. Doctoral dissertation, University of Kentucky, USA.

Elkaseh, A. M., Wong, K. W., \& Fung, C. C. (2016). Perceived ease of use and perceived usefulness of social media for e-learning in Libyan higher education: a structural equation modeling analysis. International Journal of Information and Education Technology, 6(3), 192. (Ref P34)

Evaluating usability of e-learning systems in universities. International Journal of Advanced Computer Science and Applications, 5(8), 97102. (Ref P22)

Fernandez, A., Insfran, E., \& Abrahão, S. (2011). Usability evaluation methods for the web: A systematic mapping study. Information and Software Technology, 53(8), 789-817.

Freire, L. L., Arezes, P. M., \& Campos, J. C. (2012). A literature review about usability evaluation methods for e-learning platforms. Work, 41(Supplement 1), 1038-1044.

Fuentes Pardo, J. M., Ramírez Gómez, Á., García García, A. I., \& Ayuga Téllez, F. (2012). Webbased education in Spanish Universities. A Comparison of Open Source E-Learning Platforms. Journal of Systemics, Cybernetics and Informatics, 10(6), 47-53.

Garreta-Domingo, M. and Mor, E. (2007) User Centered Desing in E-Learning Environments: from Usability to Learner Experience. In Proceedings of the EDEN 2007 Annual Conference, June 13-16. Naples Italy. (Ref P59)

Harrati, N., Bouchrika, I., Tari, A., \& Ladjailia, A. (2016). Exploring user satisfaction for e-learning systems via usage-based metrics and system usability scale analysis. Computers in Human Behavior, 61, 463-471. (Ref P26)

Hatzilygeroudis, I., Koutsojannis, C., \& Papachristou, N. (2007, June). Evaluation of usability and assessment capabilities of an eLearning System for Nursing Radiation Protection. In Computer-Based Medical Systems, 2007. CBMS'07. Twentieth IEEE International Symposium on (pp. 301-306). IEEE. (Ref P24)

Hilmi, M. F., Mustapha, Y., Ali, H. M., \& Pawanchik, S. (2012). Service Quality and Ease-of-Use of a Learning Management System Portal: Perceptions of Distance Learners. Age, 25(49), 10-9. (Ref P36)

International Standards Organization, (1998), ISO 9241 - 11, Ergonomics of human system interaction.

Jain, P. (2015). Virtual learning environment. International Journal in IT \& Engineering, 3(5), 75-84.

Jamaludin, R. \& Funn, P.L. (2007). USERS'CURRENT VIEWS ABOUT APPLIED ELEARNING COURSEWARE USABILITY: A CASE STUDY AT UNIVERSITI SAINS MALAYSIA. In: 1st International Malaysian Educational Technology Convention. 2007. (Ref P61)

Jashapara, A., \& Tai, W. C. (2011). Knowledge mobilization through e-learning systems: Understanding the mediating roles of selfefficacy and anxiety on perceptions of ease of use. Information Systems Management, 28(1), 71-83. (Ref P30)

Karahoca, D. \&Karahoca, A. (2009). Assessing effectiveness of the cognitive abilities and individual differences on e-learning portal usability evaluation. Procedia-Social and Behavioral Sciences. 1 (1), 368-380. (Ref P9)

Kiget, N.K., Wanyembi, G. \& Peters, A.I. (2014).

Kitchenham, B., \& Charters, S. (2007). Guidelines for performing systematic literature reviews in software engineering. Keele University and Durham University Joint Report.

Kitchenham, B.A., Budgen, D. \& Brereton, P. (2015). Evidence-based software engineering and systematic reviews. vol. 4. CRC Press.

Koohang, A. \&Weiss, E. (2003). Effect of prior experience with the Internet on graduate students' perception toward courseware usability and web-based distance learning instruction: An exploratory study in a hybrid instruction environment. Issues in Information Systems. 4 (2), 535-542. (Ref P18) 
Koohang, A., Paliszkiewicz, J. \& Nord, J.H. (2015). Predictors of success in e-Learning courseware usability design. Issues in Information Systems. 16 (2), 116-122. (Ref P35)

Koulocheri, E., Soumplis, A., Kostaras, N., \& Xenos, M. (2011). Usability inspection through heuristic evaluation in e-Learning environments: The LAMS case. In VII International Conference on ICT in Education, Challenges (pp. 617-630). (Ref P53)

Kumar, S., Gankotiya, A. K., \& Dutta, K. (2011, April). A comparative study of moodle with other e-learning systems. In Electronics Computer Technology (ICECT), 2011 3rd International Conference on (Vol. 5, pp. 414-418). IEEE.

Lin, K. M. (2011). e-Learning continuance intention: Moderating effects of user e-learning experience. Computers \& Education, 56(2), 515526. (Ref P15)

Liu, M., \& Zhu, Z. (2012). A case study of using eye tracking techniques to evaluate the usability of elearning courses. International Journal of Learning Technology, 7(2), 154-171. (Ref P1)

Logan, D. K., \& Neumann, T. (2010). Comparison of blackboard 9.1 and moodle 2.0. Learning Technologies Unit, Institute of Education, University of London, London, UK.

Marković, S., \& Jovanović, N. (2012). Learning style as a factor which affects the quality of elearning. Artificial Intelligence Review, 38(4), 303-312.

Masood, M., \& Musman, A. (2015). The Usability and its Influence of an e-Learning System on Student Participation. Procedia-Social and Behavioral Sciences. 197, 2325-2330. (Ref P43)

Mazzoleni, M. C., Rognoni, C., Finozzi, E., Giorgi, I., Pugliese, F., Pagani, M., \& Imbriani, M. (2008). Development of an e-learning system for occupational medicine: Usability issues. Studies in health technology and informatics, 136, 579. (Ref P13)

Meiselwitz, G., \& Trajkovski, G. (2006, June). Effects of computer competency on usability and learning experience in online learning environments. In Software Engineering, Artificial Intelligence, Networking, and Parallel/Distributed Computing, 2006. SNPD 2006. Seventh ACIS International Conference on (pp. 339-342). IEEE. (Ref P19)

Moodle.org, "Moodle Statistics," 2018. [Online]. Available: https://moodle.net/stats/. [Accessed 1430 2018].

Muhammad, A., Iftikhar, A., Ubaid, S., \& Enriquez, M. (2011). A weighted usability measure for e- learning systems. J Am Sci, 7(2), 670-686. (Ref P 5)

Nakamura, W. T., de Oliveira, E. H. T., \& Conte, T. (2017). Usability and User Experience Evaluation of Learning Management Systems- A Systematic Mapping Study. In Proceedings of the 19th International Conference on Enterprise Information Systems (ICEIS 2017) - Volume 3, pages 97-108

Nielsen, Jacob. 1993. Usability engineering. Cambridge, MA: Academic Press.

Odhiambo, O. \& Acosta, F.R. (2009). An E valuation of the Usability and Interactivity of eLearning Platforms Used In Kenyan Universities. In: E-Learn: World Conference on E-Learning in Corporate, Government, Healthcare, and Higher Education. Association for the Advancement of Computing in Education (AACE): 1016-1025. (Ref P7)

Oztekin, A., Delen, D., Turkyilmaz, A., \& Zaim, S. (2013). A machine learning-based usability evaluation method for elearning systems. Decision Support Systems, 56, 63-73. (Ref P4)

Oztekin, A., Kong, Z. J., \& Uysal, O. (2010). UseLearn: A novel checklist and usability evaluation method for eLearning systems by criticality metric analysis. International Journal of Industrial Ergonomics, 40(4), 455-469. (Ref P58)

Plantak Vukovac, D., Kirinic, V., \& Klicek, B. (2010). A comparison of usability evaluation methods for e-learning systems. DAAAM International Scientific Book, 271-288.

Plata, I. T., \& Alado, D. B. (2009). Evaluating the Perceived Usability of Virtual Learning Environment in Teaching ICT Courses. Globalilluminators. Org, 1, 63-76.

Poelmans, S., Wessa, P., Milis, K., Bloemen, E., \& Doom, C. (2008, November). Usability and acceptance of e-learning in statistics education, based on the compendium platform. In Proceedings of the International Conference of Education, Research and Innovation (pp. 110). (Ref P47)

Rahimi, A., Embi, M.A. \& Rahimi, A. (2015). Evaluation of the e-Learning developed for casemix and clinical coding: Quality of the material and usability of the system. (Ref P23)

Raspopovic, M., Jankulovic, A., Runic, J., \& Lucic, V. (2014). Success factors for e-learning in a developing country: A case study of Serbia. The International Review of Research in Open and Distributed Learning, 15(3), pp.1-23.

Reeves, T. C., Benson, L., Elliott, D., Grant, M., Holschuh, D., Kim, B., Kim, H., Lauber, E., and 
Loh, S. (2002). Usability and Instructional Design Heuristics for E Learning Evaluation. In Proc. of World Conference on Educational Multimedia, Hypermedia and Telecommunications. Vol. 2002, 1, pp.1615-1621. (Ref P49)

Rigutti, S., Paoletti, G., \& Morandini, A. (2008). Lifelong learning and e-learning 2.0: The contribution of usability studies. Journal of eLearning and Knowledge Society, 4(1), 221-229. (Ref P32)

Rugg, G. \& Petre, M. (2007) A Gentle guide to research methods. Open University Press. England.

Sakaiproject.org, 2018. Overview |Sakai. [online] at: https://sakaiproject.org/overview (accessed 04-03-18).

Santosa, P. I. (2009). USABILITY OF ELEARNING PORTAL AND HOW IT AFFECTS STUDENTS'ATTITUDE AND SATISFACTION, AN EXPLORATORY STUDY. PACIS 2009 Proceedings, 71. (Ref P54)

Santoso, H. B., Isal, R. Y. K., Basaruddin, T., Sadira, L., \& Schrepp, M. (2014, September). Inprogress: User experience evaluation of Student Centered E-Learning Environment for computer science program. In User Science and Engineering (i-USEr), 2014 3rd International Conference on (pp. 52-55). IEEE.(Ref P60)

Satam, N., Taslim, J., Adnan, W. A. W., \& Manaf, N. A. (2016, August). Usability testing of elearning system: A case study on CeL in TARUC, Johor Branch Campus. In User Science and Engineering (i-USEr), 2016 4th International Conference on (pp. 63-68). IEEE. (Ref P10)

SEPIC, T., RASPOR, S., \& POGARCIC, I. (2008). eLearning: Usability and Learnability of an ESP Online Course. In Proceedings of the 7th Wseas International Conference on E-Activities-Recent Advances in E-Activities (pp. 74-79). (Ref P20)

Shah, H. J., \& Attiq, S. (2016). Impact of technology quality, perceived ease of use and perceived usefulness in the formation of consumer's satisfaction in the context of elearning. Abasyn J. Soc. Sci, 9(1), 124-140. (Ref P27)

Ssemugabi, S., \& De Villiers, R. (2007a). Usability and learning: A framework for evaluation of webbased e-learning applications. In EdMedia: World Conference on Educational Media and Technology (pp. 906-913). Association for the Advancement of Computing in Education (AACE). (Ref P50)

Ssemugabi, S., \& De Villiers, R. (2007b). A comparative study of two usability evaluation methods using a web-based e-learning application. In Proceedings of the 2007 annual research conference of the South African institute of computer scientists and information technologists on IT research in developing countries (pp. 132-142). ACM. (Ref P2)

Sulaiman, J., Zulkifli, T., Ibrahim, K. S. K., \& Noor, N. K. M. (2009, December). Implementing Usability Attributes In E-learning System Using Hybrid Heuristics. In Information and Multimedia Technology, 2009. ICIMT'09. International Conference on (pp. 189-193). IEEE. (Ref P28)

Tharangie, K. G. D., Irfan, C. M. A., Marasinghe, C. A., \& Yamada, K. (2008). Kansei Engineering Assessing System to enhance the usability in elearning web interfaces: Colour basis. In 16th International Conference on Computers in Education (Vol. 1, No. 1, pp. 145-150). (Ref P29)

Theng, Y. L., \& Sin, J. (2012). Evaluating usability and efficaciousness of an e-learning system: A quantitative, model-driven approach. In Advanced Learning Technologies (ICALT), 2012 IEEE 12th International Conference on (pp. 303-307). IEEE. (Ref P21)

Thowfeek, M. H., \& Salam, M. N. A. (2014). Students' Assessment on the Usability of Eleaming Websites. Procedia-Social and Behavioral Sciences, 141, 916-922. (Ref P37)

Torun, F., \& Tekedere, H. (2015). The Usability Analysis of An E-Learning Environment. Turkish Online Journal of Distance Education. (Ref P42)

Van der Merwe, T. M., \& Van Heerden, M. E. (2013, October). Ease of use and usefulness of webinars in an open distance learning environment: an activity theory perspective. In Proceedings of the South African Institute for Computer Scientists and Information Technologists Conference (pp. 262-270). ACM. (Ref P17)

Van Nuland, S. E., \& Rogers, K. A. (2016). The anatomy of E- Learning tools: Does software usability influence learning outcomes?. Anatomical sciences education, 9(4), 378-390. (Ref P38)

Venkataraman, S., \& Sivakumar, S. (2015). Engaging students in Group based Learning through e-learning techniques in Higher Education System. International Journal of Emerging Trends in Science and Technology, 2(01), 1741-1746.

Wiklund-Engblom, A. (2010, October). Triangulating methods for exploring the link between user experience and e-learning. In Proceedings of the 14th International Academic MindTrek Conference: Envisioning Future Media Environments (pp. 171-177). ACM. (Ref P46) 
Yusof, A. N. M., \& Ahmad, N. L. (2012). An Investigation on the Relationship between Online Distance Learning with Learning Usability. Procedia-Social and Behavioral Sciences, 65, 1066-1070. (Ref P8)

Yusof, A. N. M., Kassim, E., \& Zamzuri, N. H. (2010, December). Online distance learning: Quality characteristics and usability evaluation. In Science and Social Research (CSSR), 2010 International Conference on (pp. 575-579). IEEE. (Ref P33)

Zamzuri, N. H., Kassim, E. S., \& Shahrom, M. (2010, January). The role of cognitive styles in investigating E-learning usability. In e-Education, e-Business, e-Management, and e-Learning, 2010. IC4E'10. International Conference on(pp. 3-6). IEEE. (Ref P40) 